\title{
Growth of decotylised embryonic axes of radish on synthetic medium
}

\author{
A. HOFFMANNOWA
}

\section{INTRODUCTION}

Embryos isolated from mature seeds, deprived of the endosperm and cotyledons are often capable of normal development in conditions of a culture in vitro. This ability has been confirmed several times (Narayanaswami and Norstog 1964, Raghavan 1966). However, in comparison with seedlings, the growth and development of such embryos is often weaker and slower, and the metabolic changes take place at a lower level (often under ,starvation" conditions) or are altered.

Such conclusions were arrived at by Czosnowski (1962) and Michejda (1966) among others when they studied the comparative nitrogen metabolism in seedlings and isolated embryonal axes of lupine and barley. Lupine is a plant whose seeds are very rich in protein, while seeds of barley are characterised by a low protein level and a large content of starch.

In this context it seemed interesting to study the same parameters in radish in whose seeds fats are the main storage material accumulated in the cotyledons.

\section{MATERIAL AND METHODS}

For the experiments seeds of radish, Raphanus sativus L. var. radicula D.C., Sax'es cultivated variety, obtained from the culture of Freege, have been used. The seeds were segregated into 3 classes with the help of sieves. The most numerous class was used for the experiment, namely the seeds which did not pass through a sieve with holes $2,5 \mathrm{~mm}$ in diameter but passed through the sieve with holes $3 \mathrm{~mm}$ in diameter. The seeds were washed in absolute ethanol for 1 min., sterilized in $0.2 \%$ solution of mercuric chloride, washed three times with sterile water, and soaked in double distilled water for 2 hours. Then some of the seeds were placed in test-tubes with $0.75 \%$ water agar. This was the control material. From the remaining seeds the embryonal axes were isolated and placed in test-tubes with a sterile medium. Heller's medium was used (Heller 1954) with the addition of $4 \%$ sucrose and $0.75 \%$ agar.

The culture of whole seedlings and isolated axes was conducted in a thermostat at a temperature of $24^{\circ} \mathrm{C}$ for 12 days,

a) in darkness and

b) under a continuous fluorescent illumination (1600 lux). 
The samples were taken in the following fashion:

Seeds soaked for 2 hours, seedlings and isolated axes after 3, 7, and 12 days of culture. In the case of seedlings the fresh weight of roots, hypocotyls and cotyledons were recorded. In order to obtain the dry weight the material was diced for 12 hours at a temperature of $80^{\circ} \mathrm{C}$. Each time the measurements were made on 150 to 200 seedlings or isolated axes.

In the dry, powdered material the nitrogen fractions were determined. Total nitrogen (without $\mathrm{NO}_{3}$ ) was determined by micro-Kjeldahl method. Soluble nitrogen was determined in the following manner: $50-60 \mathrm{mg}$ of dry material was suspended in $10 \mathrm{ml} \mathrm{H}_{2} \mathrm{O}$ and heated for $15 \mathrm{~min}$. in a boiling water-bath, then filled up with $95 \%$ ethanol to $25 \mathrm{ml}$ and centrifuged. Soluble nitrogen was determined by the Kjeldahl method in $5 \mathrm{ml}$ samples of the supernatant. Protein nitrogen was inferred and the $\mathrm{N}_{\text {protein }} / \mathrm{N}_{\text {soluble }}$ ratio calculated.

In this paper, both in the text and on graphs, the axes of seedlings are marked A and the decotylised axes are marked B.

\section{RESULTS}

The initial material, namely seeds soaked for 2 hours had the following parameters as shown in the table below:

\begin{tabular}{l|c|c|c|c|c|c}
\hline & $\begin{array}{c}\text { Fresh wt. } \\
\mathrm{mg}\end{array}$ & $\begin{array}{c}\text { Dry wt. } \\
\mathrm{mg}\end{array}$ & $\begin{array}{c}\text { Total N } \\
\mu \mathrm{g}\end{array}$ & $\begin{array}{c}\text { Protein N } \\
\mu \mathrm{g}\end{array}$ & $\begin{array}{c}\text { Soluble N } \\
\mu \mathrm{g}\end{array}$ & $\begin{array}{c}\text { Prot. N } \\
\text { Solub. N }\end{array}$ \\
\hline $\begin{array}{l}\text { Cotyledons } \\
\text { (a pair) }\end{array}$ & 11.0 & 7.1 & 305 & 272 & 33 & 8.2 \\
Axis (one) & 2.3 & 1.4 & 72 & 67 & 5 & 13.4 \\
\hline
\end{tabular}

Seedling axes (A) and decotylised axes (B)

Fresh weight (Fig. 1)

A. There is an intensive growth, particularily of the hypocotyls in the darkness (almost 3 times as great as in light) for the first 7 days, and then an inhibition of growth (in light) or even a slight loss of weight (in darkness).

B. Growth is as intensive as of the seedlings. Light does not inhibit the growth in the least. In the hypocotyl fresh weight reaches a value more than twice as high as in the axes of seedlings.

Dry weight (Fig. 2)

A. In the darkness dry weight increases. In the root it is slow but continuous while in the hypocotyl it is faster but only until the 7th day. This is followed by a slight lowering. In light the dry weight of the hypocotyl and root drops until the 3rd day. After that it increases.

B. There is an even increase in dry weight in the isolated axes, somewhat weaker 


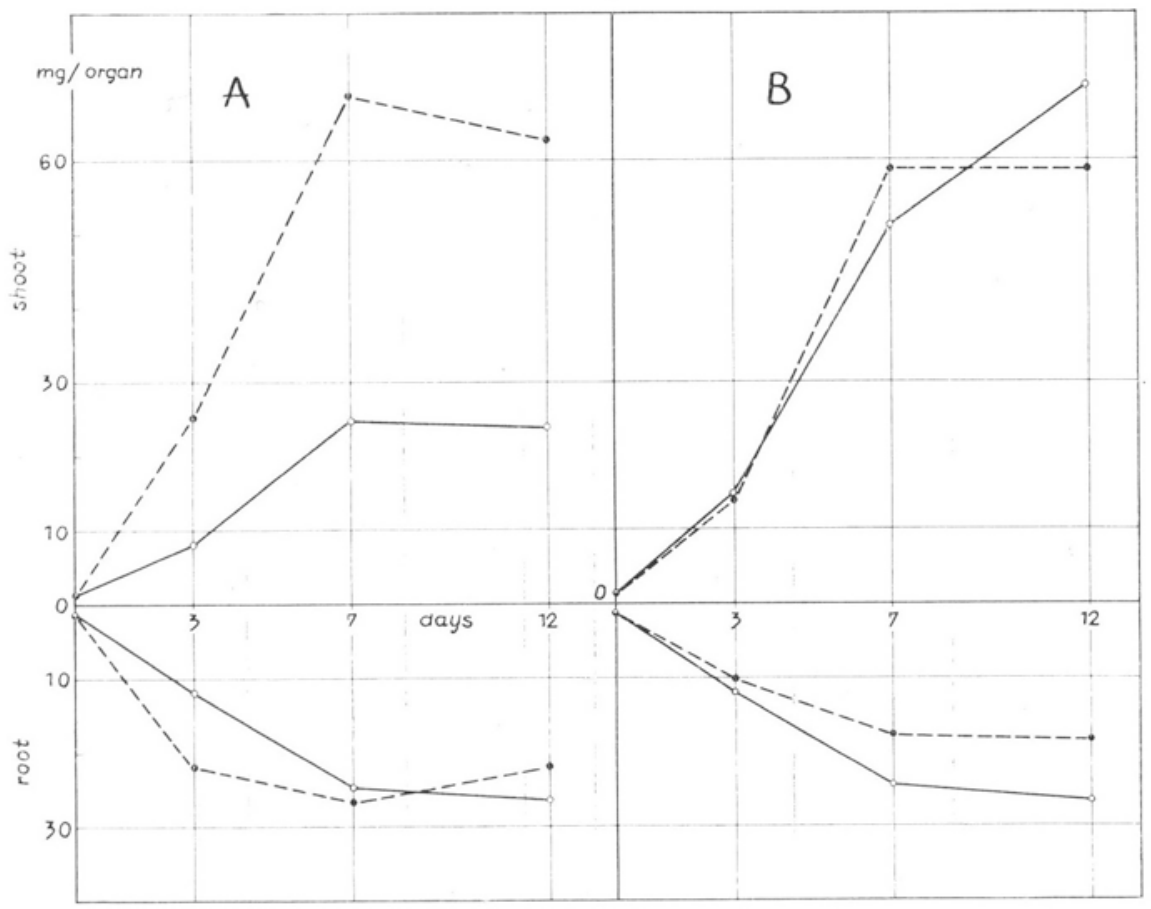

Fig. 1. Fresh weight (mg per organ) of normal seedling axes $(A)$ and excised embryonic axes $(B)$ cultured in vitro. Above "0": shoot system, below "0": root system. Solid line - cultures under light, broken line - cultures in the dark.

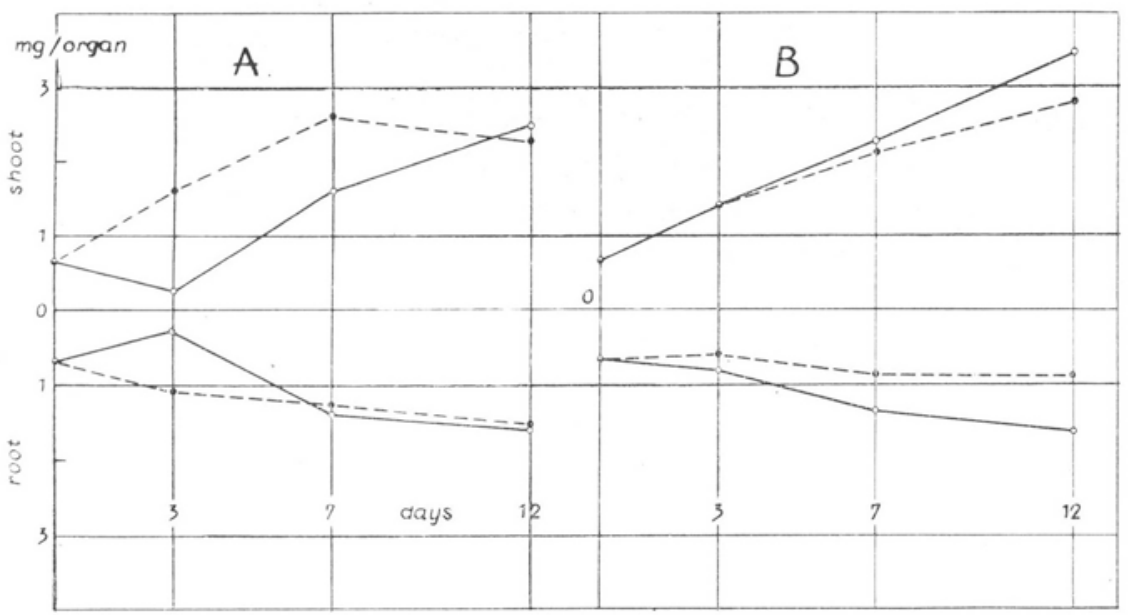

Fig. 2. Dry weight (mg per organ) of normal seedling axes $(A)$ and excised embryonic axes $(B)$ cultured in vitro. (For further explanation see Fig. 1). 
in the darknes. Quantitatively this increment is the same, and even slightly greater than in the axes of seedlings (hypocotyl in the light).

Total nitrogen (fig. 3)

A. In the light the level of total nitrogen decreases until the 3rd day. After that the values increase reaching in the hypocotyl a value twice as high as originally. In

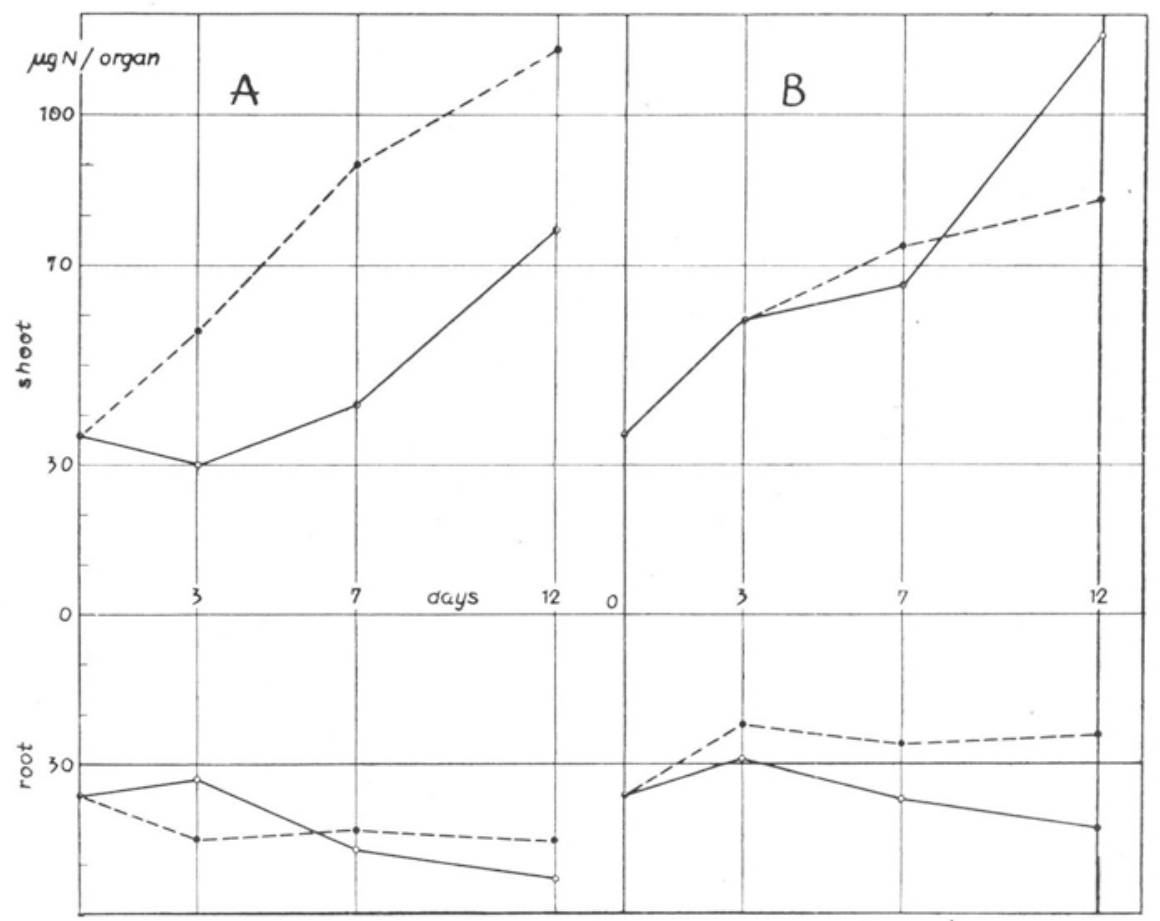

Fig. 3. Total nitrogen ( $\mu$ g per organ) in normal seedling axes $(A)$ and excised embryonic axes ( $B$ ) cultured in vitro. (For further explanation see Fig. 1.).

the darkness the nitrogen level in the hypocotyl increases quickly, so that on the 12 th day it is thrice as high as originally. In the root, from the 3rd day onwards the amount of nitrogen does not undergo changes.

B. In the hypocotyl the amount of nitrogen increases. It does so particularily quickly in the light from the 7th day onwards, so that on the 12th day it is almost 4 times higher than the amount of nitrogen contained in the axes at the time of their isolation. In the root, both in the light and in the darkness, the level of nitrogen decreases sill the 3rd day, after which it stays almost unchanged in the darkness while in the light it is gradually on the increase.

Protein nitrogen (Fig. 4)

A. Just as in the case of total nitrogen and of dry weight, it has been found in the seedlings kept in light, both in the roots and in the hypocotyls, that the amount of protein nitrogen decreases until the 3rd day. A similar phenomenon in 


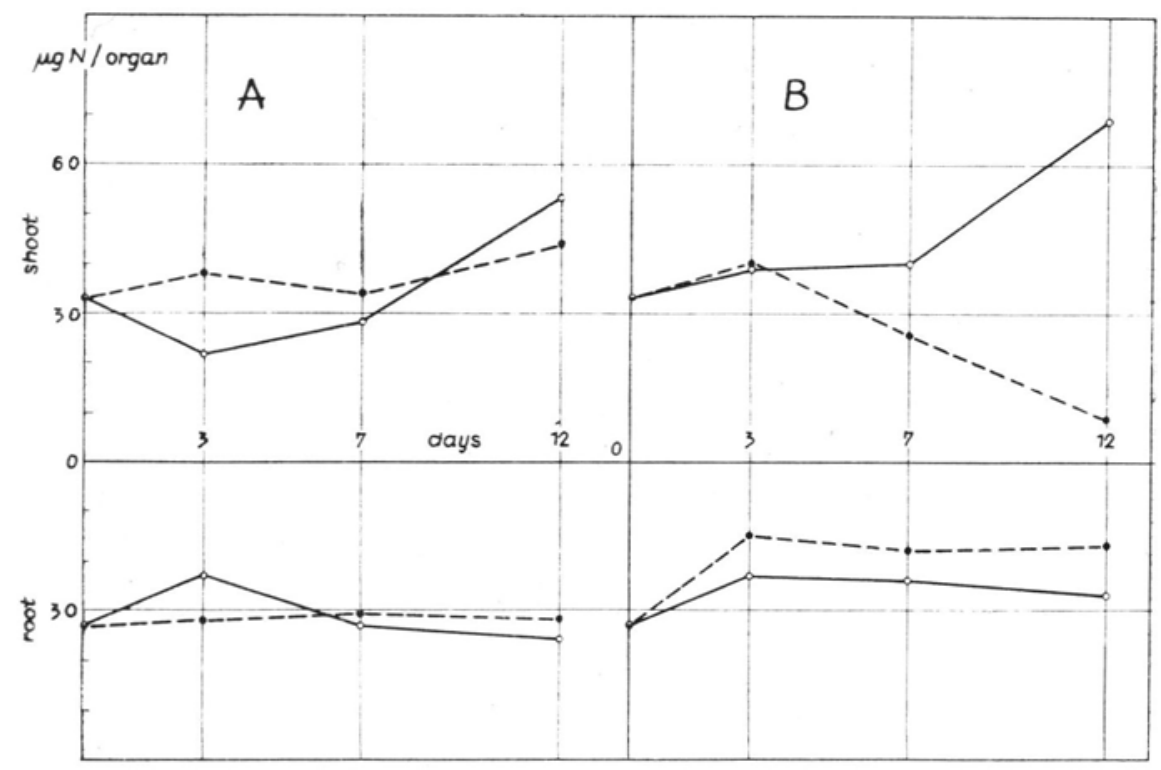

Fig. 4. Protein nitrogen ( $\mu$ g per organ) in normal seedling axes $(A)$ and excised enbryonic axes ( $(b)$ (For further explanation see Fig. 1).

lupine, though not in seedlings but in embryonal axes, has been observed by Czosnowski (1962) who explains it as exodiffusion of substances into the medium.

In the darkness, the level of protein nitrogen in roots does not undergo changes throughout the culture period. In the hypocotyls small fluctuations can be observed.

B. In the hypocotyl there is a small increase in th is nitrogen fraction up to the 3 rd day. In the light protein nitrogen continues to increase, while in darkness. there is a rapid decline, to a level much below the initial. There is a distinct dominance of protein degradation over new synthesis.

In the roots, both in the light and in the darkness, protein nitrogen remains more or less on the same level, and until the the end of the culture period it does not surpass the initial level.

Soluble nitrogen (Fig. 5).

A. In the light the content of soluble nitrogen increases slowly in the hypocotyl and in the root. In darkness is a rapid incredse of this nitrogen fraction in the hypocotyl while in the root it does not change after the $3 \mathrm{rd}$ day.

B. The shape of the curves is similar, however the disparity between the values in the light and in darkness in the hypocotyl is not as great as it was in the case of seedlings. 


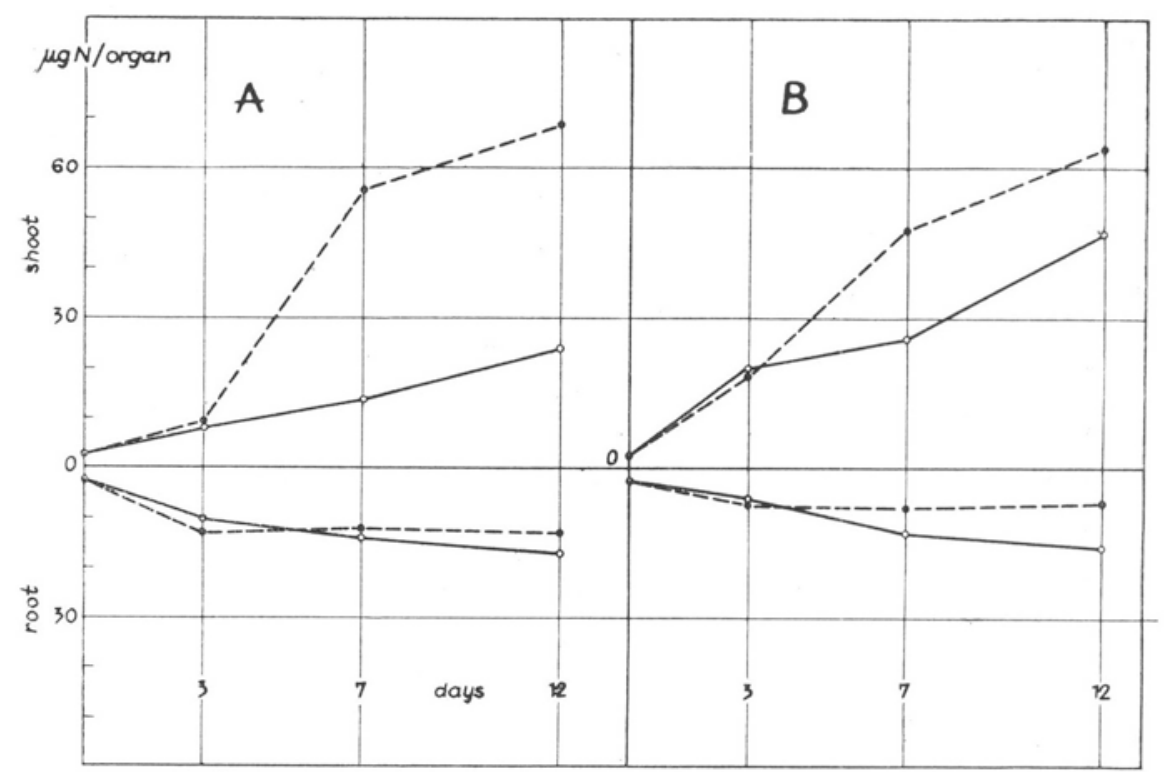

Fig. 5. Soluble nitrogen ( $\mu$ g per organ) in normal seedling axes $(A)$ and in excised embryonic axes $(B)$ cultured in vitro. (For further explanation see Fig. 1).

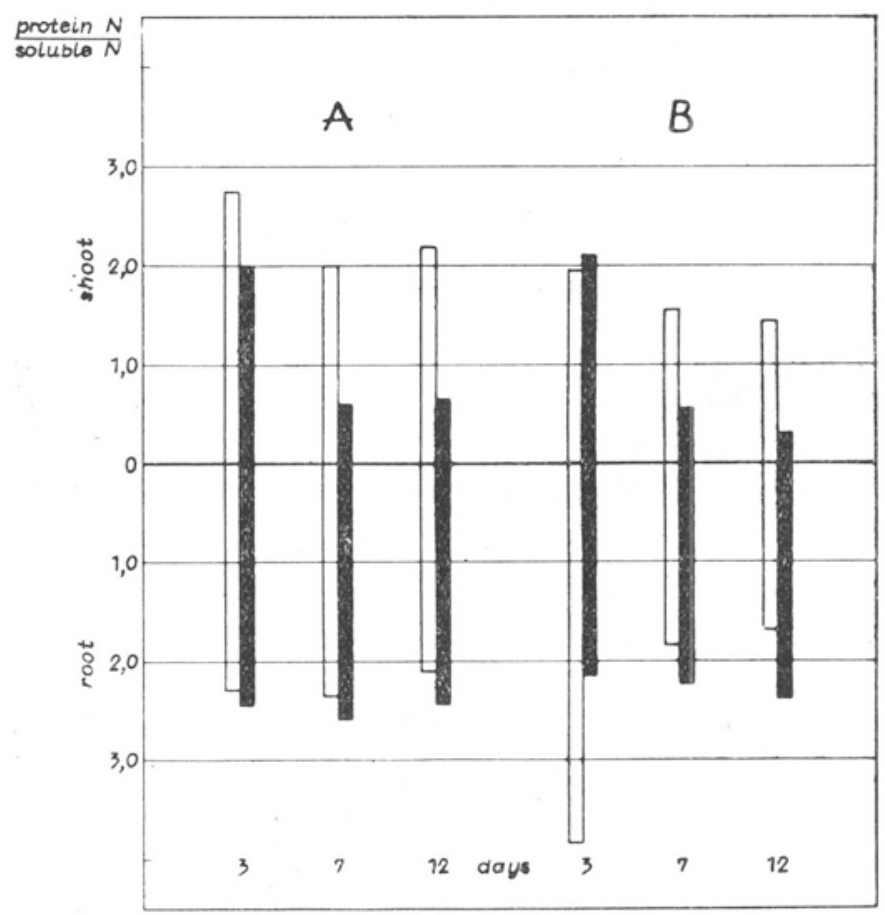

Fig. 6. $\mathrm{N}_{\text {protein }} / \mathrm{N}_{\text {soluble }}$ ratio in normal seedling axes $(A)$ and in excised embryonic axes $(B)$ after 3,7 , and 12 days ( $f$ culture in vitro. Above " 0 " level: shoot system, below " 0 ": root system. White columns - cultures under light, black columns - cultures in darkness. 


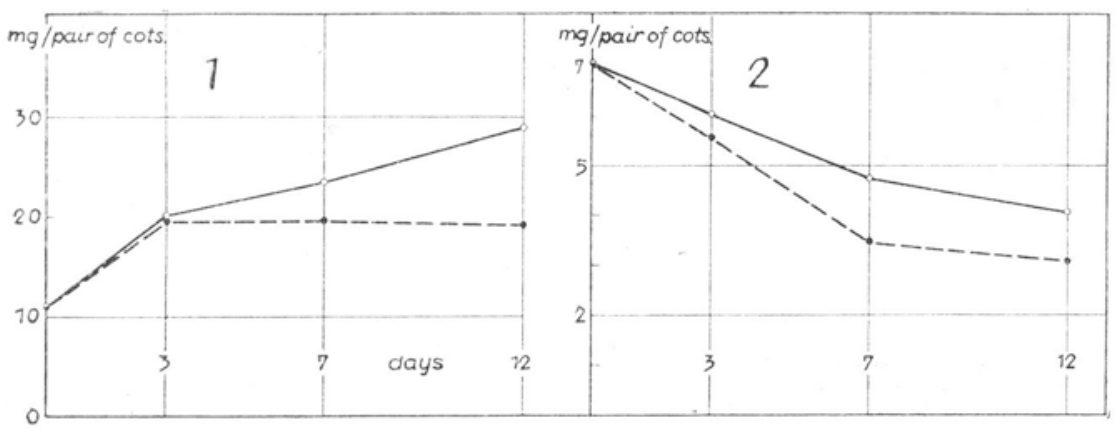

Fig. 7. Fresh ( $I$ ) and dry (2) weight of cotyledons (mg per pair of cotyledons). Solid line - cultures under light, broken line - cultures in the dark.

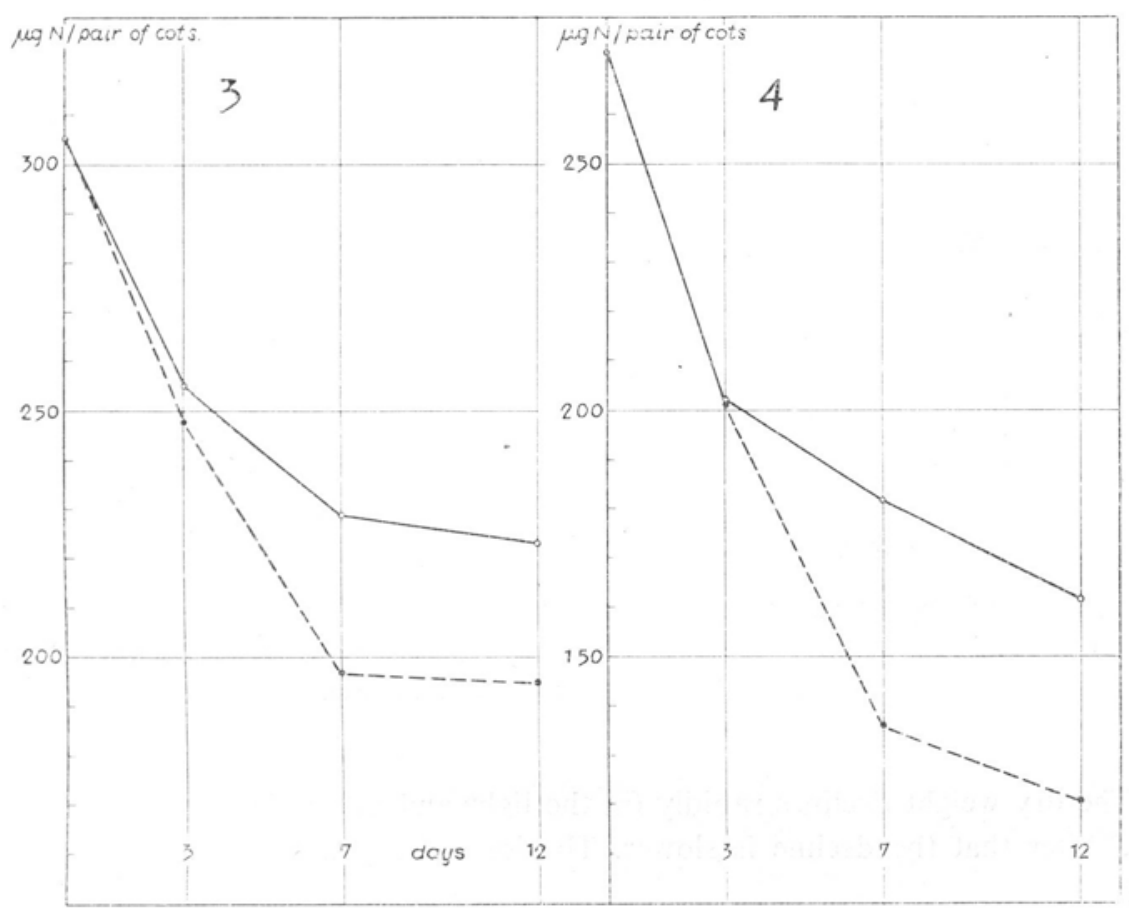

Fig. 8. Total nitrogen (3) and protein nitrogen (4) in cotyledons ( $\mu$ g per pair of cotyledons).

$\mathrm{N}_{\text {protein }} / \mathrm{N}_{\text {soluble }}$ ratio (Fig. 6).

A. The hypocotyls of seedling axes in light have the ratio values 2 or more, but not more than 3. In darkness it falls from about 2 to 0.5 . In seedling roots the value is more or less constant both in light and in the darkness. It varies from 2.0 to 2.5 .

B. In the hypocotyls of isolated axes this ratio is about the same in the third day (about 2.0), and then it slowly declines in light (to about 1.5) and rapidly 
declines in darkness (to below 0.5). On the other hand in the root in light the ratio is more than 3.5 on the third day and drops rapidly to almost 2.0 on the 7 th day, then declining very slightly till the 12 th day. In darkness values of this ratio increase slightly from about 2.0 to no more than 2.5 on the 12th day.

\section{Cotyledons}

Fresh and dry weight (Fig. 7).

The cotyledons of seedlings increase in fresh weight until the 3rd day of germination, and no more after that in darkness. In light the fresh weight continues to increase.

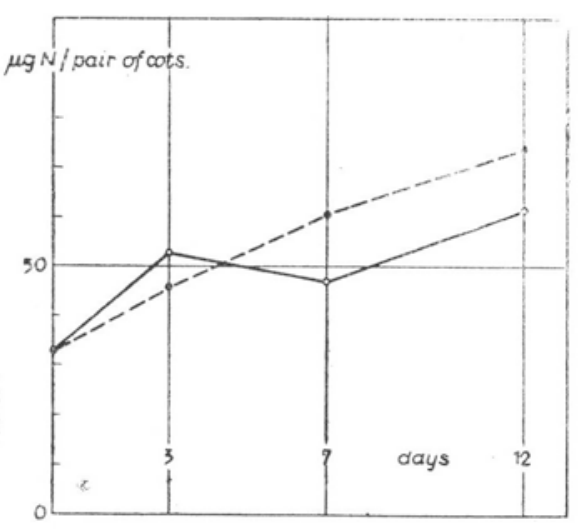

Fig. 9

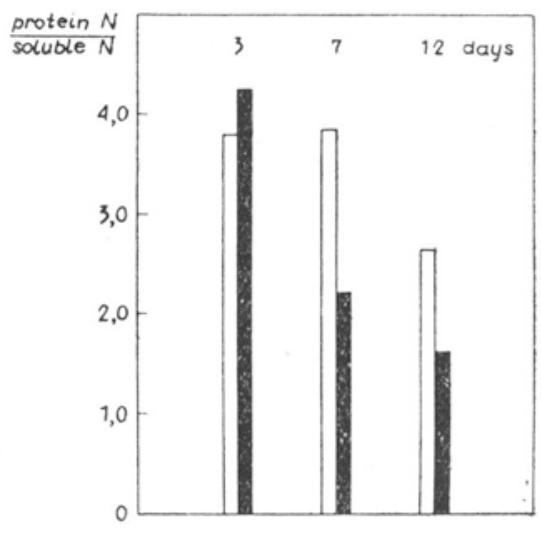

Fig. 10

Fig. 9. Soluble nitrogen ( $\mu \mathrm{g}$ per pair of cotyledons) in cotyledons.

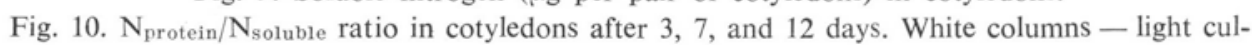
tures, black columns - dark cultures.

The dry weight declines rapidly (in the light and in the darkness) until the 7th day. After that the decline is slower. The loss of dry weight is greater in darkness.

\section{Total nitrogen (Fig. 8).}

Total nitrogen drops rapidly till the 7th day (in the light this decline is somewhat slower after the 3rd day), after which the decline is minimal. In darkness the decline in total nitrogen level in the cotyledons is much greater.

\section{Protein nitrogen (Fig. 8).}

Both in light and in darkness protein nitrogen level rapidly declines till the 3rd day. After that the rate of decline is slower in light (cotyledons at the time are already green) while in the darkness it remains fast. 
Soluble nitrogen (Fig. 9).

The amount of this nitrogen fraction increases. In darkness the increase leads uniformly to a level twice as high as initial on the 12th day. In light there is a drop from the 3 rd to the 7 th day, after which there is new increase.

$\mathrm{N}_{\text {protein }} / \mathrm{N}_{\text {soluble }}$ ratio in the cotyledons (Fig. 10).

In darkness this ratio declines from about 4.0 to 1.5 . In light it remains more or less constant (about 3.5 ) till the 7th day after which it declines to about 2.5 on the 12th day.

Apart from the results presented above no other measurements were made. It needs however to be mentioned that the root system of the isolated embryonic axes is just as well developed as in seedlings not deprived of the cotyledons. Lateral roots are numerous and long, just as in seedlings.

\section{DISCUSSION}

The results obtained permit the definite conclusion that isolated embryonic axes of radish are independent and selfsufficient as far as their nitrogen metabolism is concerned. Developing on a simple medium the axis is able to absorb both the nitrogen (applied as $\mathrm{NaNO}_{3}$ ) and sucrose. The measured values are not lower and are often higher than those in axes of seedlings. The isolated axis develops a root system just as well as a seedling. Light does not have an inhibitive effect on its growih. Thus the development is very different from that of isolated embryonic axes of lupine in which Czosnowski (1962) found a much weaker growth compared with a seedling, a very poor development of the rooting system, incapacity to absorb nitrogen from the medium (,starvation" metabolism of nitrogen) and a shift of the balance in the direction of protein synthesis. This was best examplified by a several times higher protein to soluble nitrogen raiio in the isolated axes than in those from seedlings.

The axes isolated from seeds of barley have demonstrated a greater metabolic independence (Michejda 1966), however also in this case the parameters obtained for the axes were much lower than those from seedlings. Only the $\mathrm{N}_{\text {protein }} / \mathrm{N}_{\text {soluble }}$ ratio in seedlings and embryonic axes did not demonstrate drastic differences as was the case with lupine. The values were more or less close to one another.

An embryo developing from a zygote is a heterotrophic structure. With the embryo's development its selfsufficiency increases and it reaches its fullness on maturity. However as can be seen from the results of Czosnowski (1962), Michejda (1966) and those obtained in the present study, this selfsufficiency can be of a varying degree when the natural food store is replaced experimentally. It is possible to arrange the mentioned plants in a sequence starting from lupine, which is the least selfsufficient and is dependent on interaction with the cotyledons even for the production of lateral roots (an embryonal axis forms almost no lateral roots when cultured in vitro (Fries 1960, and unpublished data from our laboratory), then barley, 
somewhat more selfsufficient and finally radish, whose embryonal axis is selfsufficient in all respects.

From the results presented above it could be supposed that in oil plants the metabolism in the first phases of germination follows a somewhat different course. This supposition finds support in results of such studies as the one conducted on the oily radish (unpublished data from our laboratory) or from the different ways in which lupine and cabbage embryos react to the kind and concentration of sugar in the medium (Hoffmannowa 1964). Admittedly all the oil plants mentioned above belong to the Cruciferae and this difference could be a characteristic of this family. However the studies on the organic acids and on the cycle of tricarboxylic acids (Täufel and Pohloudek-Fabini 1955; Radecke 1965) indicate clearly the biochemical and metabolic differences between germinating seeds of protein, starchy and oily plants belonging to various systematic groups.

From the suggested sequence: lupine, barley, radish it seems to appear that the degree of selfsufficiency of the isolated embryonic axes cultured on a simple, static medium can depend among other things on the amount of protein being at the disposal of the axis in the seed (the more protein - the smaller the selfsufficiency).

\section{SUMMARY}

1. Complete seedlings and isolated, decotylised embryonal axes of radish were cultivated for 12 days in vitro in light and in the darkness. Seedlings on $0.75 \%$ water agar, and embryonal axes on Heller's mineral solution supplied with $4 \%$ sucrose and $0.75 \%$ agar (under sterile conditions).

2. Fresh and dry weight were measured and the total and soluble nitrogen were estimated analytically.

3. Isolated and decotylised axes demonstrate the same or even better growth (fresh and dry weight), and have the same or even higher level of various nitrogen fractions than the axes in the seedlings. lings.

4. The $\mathrm{N}_{\text {protein }} / \mathrm{N}_{\text {soluble }}$ ratio in the isolated axes was essentially the same as in normal seed-

5. Roots of isolated axes were just as well developed as in the seedlings.

6. The results obtained were discussed and compared in particular with those obtained by Czosnowski (1962) for lupine and by Michejda (1966) for barley.

The isolated embryonal axes of radish demonstrate a biochemical selfsufficiency. They successfully utilize the mineral nitrogen of the medium. It has been found that the dynamics of nitrogen metabolism in the isolated axes is the same as in normal seedlings. This statement is made on the

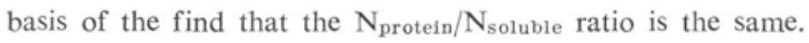

\section{Department of Plant Physiology}

A. Mickiewicz University

Poznań, Stalingradzka 14

\section{REFERENCES}

Czosnowski J., 1962, Metabolism of excised embryos of Lupinus luteus L. III. Comparative study of cultured embryos and normal seedling axes. Acta Soc. Bot. Pol. 31:693.

Hoffmannowa A., 1964, Some aspects of sugar nutrition of excised embryos of Lupinus luteus L. and Brassica oleracea L., Acta Soc. Bot. Pol. 33:193. 
Heller R., 1954, Recherches sur la nutrition minérale des tissus végétaux cultivés in vitro, Ann. Sc., Nat. Bot. Biol. Vég. 14:1.

Michejda J., 1966, Growth of excised embryonic axes of barley on synthetic medium, Acta Soc.

Bot. Pol. 35:69.

Narayanaswami S., Norstog K., 1964, Plant embryo culture, Bot. Rev., 30:587.

Radecke H. R., 1965, Beiträge zur Entwicklungsphysiologie und Biochemie der Samen, Die

Pharmazie, 20:1.

Raghavan V., 1966, Nutrition, growth and morphogenesis of plant embryos, Biol. Rev. 41:1. Täufel K., Pohloudek-Fabini R., 1955, Das Verhalten der Citronensäure bei der Keimung von Cerealien-, Leguminosen- und Ölsamen, Bioch. Zscht. 326:280.

Wzrost izolowanych embrionalnych osi rzodkiewki na syntetycznej pożywce

\section{Streszczenie}

1. Całe siewki i izolowane osie embrionalne rzodkiewki hodowano przez 12 dni in vitro na świetle i w ciemności. Siewki na $0.75 \%$ agarze wodnym, osie embrionalne na mineralnej pożywce Hellera z dodatkiem $4 \%$ sacharozy i $0.75 \%$ agaru (w warunkach sterylnych).

2. Przeprowadzano pomiary świeżej i suchej masy i oznaczono azot całkowity i rozpuszczalny.

3. Izolowane osie wykazują taki sam lub nawet lepszy wzrost (świeża i sucha masa), taki sam lub nawet wyższy poziom różnych form azotu jak osie siewek.

4. Stosunek $\mathrm{N}_{\text {biakk. }} / \mathrm{N}_{\text {rozpuszez. }}$ w izolowanych osiach był zasadniczo taki sam jak w normalnych siewkach.

5. Korzenie izolowanych osi były równie dobrze rozwinięte jak u siewek.

6. Otrzymane wyniki zostały omówione i porównane przede wszystkim z wynikami Czosnowskiego (1962) dla łubinu i Michejdy (1966) uzyskanymi w badaniach nad jęczmieniem. Izolowane osie embrionalne rzodkiewki wykazywały biochemiczną samowystarczalność. Doskonale wykorzystują $\mathrm{N}$ mineralny pożywki. Stwierdzono, że dynamika ich metabolizmu azotowego jest taka sama jak u normalnych siewek. Podstawą do tego twierdzenia jest stosunek $\mathrm{N}_{\text {bialk }} \cdot \mathrm{N}_{\text {rozp }}$. 